\title{
Strengthening an Educational Innovation Strategy: Processes to Improve Gamification in Calculus Course through Performance Assessment and Meta-evaluation
}

\author{
Elvira G. Rincon-Flores ${ }^{1, *}$, Katherina Gallardo ${ }^{1}$, Juana María de la Fuente ${ }^{1}$ \\ ${ }^{1}$ Tecnologico de Monterrey (ITESM), MÉXICO \\ *CORRESPONDENCE: $\square$ elvira.rincon@itesm.mx
}

\begin{abstract}
The present study details the implementation of an improvement process for a gamification activity from a Calculus course for undergraduate students aimed to develop mathematical modeling competencies. The improvement process was studied taking into account three types of data: the results of the students' performance assessment, the meta-evaluation of the educational and proactive effects and gamification costs, and data on the level of satisfaction achieved on the educational activity. The results of 50 performance assessments were analyzed, as well as the results from the meta-evaluation process carried out by the course's teacher. The study concludes that while it is true that gamification is a strategy that introduces a high level of innovation and brings the type of motivation and emotion that encourages learning, its educational intent can be further strengthened by including performance assessment and metaevaluation processes to better understand its function and make adjustments to its design in a timely manner.
\end{abstract}

Keywords: competencies, higher education, gamification, meta-evaluation, mathematical modeling

\section{INTRODUCTION}

\section{Educational Innovation}

Innovation as a term is becoming increasingly important in the field of education. Proof of this are the technological advances that have enhanced and invigorated educational processes (Zavalza, 2004). Innovations arise from a problem in which human and material resources are used in conjunction to reach a solution resulting in better quality for the educational, social or business environment (Rubia, Anguita, Jarrín \& Ruiz, 2010), that is, any environment in which there is an improvement opportunity (Fidalgo-Blanco \& SeinEchaluce, 2014), thus there could be a transformation of knowledge, resulting in individual or collective benefits (Ramírez-Montoya, 2012).

For Zavalza and Zavalza (2012) there are three essential elements when developing an innovation: openness, updating and improvement of quality. Openness is the ability to adapt, as well as the development or improvement of attitudes, knowledge, skills and resources. Updating consists in being knowledgeable regarding the latest advances related to the innovation implemented. Improvement of quality requires evaluating the extent to which innovation improves the process. This last element is what determines whether the innovation fulfills its fundamental purpose, because it is not enough to use the latest technological releases

\footnotetext{
Article History: Received 23 September $2017 \bullet$ Revised 16 January $2018 \bullet$ Accepted 28 February 2018

(C) 2018 The Author(s). Open Access terms of the Creative Commons Attribution 4.0 International License (http://creativecommons.org/licenses/by/4.0/) apply. The license permits unrestricted use, distribution, and reproduction in any medium, on the condition that users give exact credit to the original author(s) and the source, provide a link to the Creative Commons license, and indicate if they made any changes.
} 
or educational trends, they must also show the manner in which they contribute to the improvement of the training processes (García-Peñalvo, García de Figuerola \& Merlo, 2010, García-Peñalvo, 2015). In addition, these ideas suggest that the evaluation of innovation will depend on the context and on the people applying the innovation. In their study, Borrego, Froyd and Hall (2010) established four criteria for evaluating innovations in engineering education: (a) There is research on the innovation to be adopted; (b) Innovations have been universally adopted in the institution; (c) There is evidence of its effect on student learning or retention; and (d) Innovation stands apart from other innovations. These criteria are interesting and can be useful for evaluating various educational innovations in any area of knowledge.

\section{Gamification as a Strategy of Educational Innovation}

Currently, there are several innovative educational trends. Gamification is one of them, which is characterized by using elements of games in non-game contexts (Deterding, Khaled, Nacke, \& Dixon, 2011). Gamification is a strategy that only recently has been incorporated into education, although its existence dates back to the Second World War (Dicheva, Dichev, Agre \& Angelova, 2015). The term was established by Nick Pelling in 2002, but it was in 2010 when it began to enjoy widespread success in the business sector, and now it is being implemented in education (Rodríguez \& Santiago, 2015).

One of the objectives of gamification in education is to engage and motivate students (López Fernández, Alarcón, Rodríguez \& Casado, 2014, Tsai, Huang, Hou, Hsu \& Chiou, 2016) since it uses elements that favor extrinsic and intrinsic motivation. For example, winning badges favors extrinsic motivation (Davis \& Sigh, 2015), while beating a challenge favors intrinsic motivation (Surendeleg, Murwa, Yun \& Kim, 2014). It also offers the opportunity to experiment with rules, emotions and social roles (Lee \& Hammer, 2011), in which skills and attitudes such as collaboration, self-regulation of learning and creativity are developed (Caponetto, Earp \& Ott, 2014; Villalustre \& Del Moral, 2015).

In addition, educational games are a unique opportunity to integrate cognitive, affective and social aspects into learning (Domínguez, Saenz-De-Navarrete, De-Marcos, Fernández-Sanz, Pagés, \& Martínez-Herráiz; Fox, 2015; Pulos \& Sneider, 1994). In the case of Mathematics instruction, several studies state that using gaming strategies has been favorable (Kebritch, Hirumi \& Bai, 2010, Muñiz-Rodriguez, Alonso \& RodriguezMuñiz, 2014, Chamoso, Durán, García, Martín \& Rodríguez, 2004). In a study by Rincón-Flores, RamírezMontoya and Mena (2016), the authors found that gamification based on challenges sustained long-term learning; in Goehle (2013), it was noted that the students improved their performance on their Mathematics homework. Similarly, Nisbet and Williams (2009) found that gamification improved students' attitudes in terms of attention and participation, while contributing to improve learning and reduce mathematical anxiety (Gómez-Chacón, 2000; Tobias \& Weissbrod, 1980).

\section{Performance Assessment and Meta-evaluation}

The competency development process in the Competency-Based Education Model (CBEM) begins and ends with the performance assessment, which is defined as a process in which students must demonstrate that they have developed a series of capabilities. This demonstration is done both by transferring their applied knowledge to solve a problem, and by displaying a series of skills, attitudes and values to tackle a complex task, under certain conditions and in a given context (Bartels, Boomer \& Rubin, 2000; Bogo, Reghr \& Woordford, 2006; Hancock, 2007).

Deciding which processes will help estimating the level of capacity development is one of the most important tasks that the teacher must perform. Therefore, it requires proposing different strategies and assessment mechanisms, as well as providing feedback to the students so that they can reach the expected levels of performance in a gradual manner.

In addition to the evaluation of the apprentice, the assessment has another sometimes ignored purpose, related to the decision making process to improve evaluation processes. This type of evaluation is called metaevaluation. A meta-evaluation, according to Stufflebeam (2011), is the process that helps to delineate, obtain and apply descriptive and judicious information about the usefulness, feasibility and accuracy of an evaluation and its systematic nature. This type of evaluation is also part of the international evaluation standards issued by the Joint Committee on Standards of Educational Evaluation (JCSEE, 2017).

The meta-evaluation is carried out based on the documentation of the evaluation processes and results, which must be done in a wide-ranging manner to establish criteria around the fulfillment of learning objectives, instrument design, application, data collection and results. From this information, two types of 
meta-evaluation can be generated: internal and external. In the internal meta-evaluation, evaluators must examine the accountability of the evaluation design, the procedures used, the information gathered and the results. The usefulness of this first type of meta-evaluation focuses on issuing judgments for formative and summative evaluation processes. In the external meta-evaluation, sponsors, clients, evaluators and other stakeholders of the evaluation should encourage meta-evaluations, using the desired results as a reference to compare against the results achieved. Both types of meta-evaluation are key to the gradual improvement of the teaching competencies related to the evaluation of learning (Stufflebeam, 2011).

In both the performance assessment and the meta-evaluation, reference frames are needed to delimit the expected results and, in turn, to carry out the operationalization of the levels in order to be able to issue results. In the case of performance assessment, depending on the competencies or learning objectives that one wishes to achieve, taxonomies of thought, psychomotor performance or social-affective domain can be used for its operationalization (Anderson, 2001; Karthworhl, 1968; Marzano \& Kendall, 2007; Simpson, 1974 (in Kent, 2004)). Their use has been deemed valuable in different studies (Gallardo et al., 2012, Jackson, Beer \& White, 2016, Vásquez, 2015). Regarding the meta-evaluation, Stufflebeam (2011) proposes a structural logic to conduct it, based on criteria that integrates both quantitative and qualitative information to issue judgments.

On the research carried out in the field of performance assessment linked to gamification, SánchezCarmona, Robles and Pons (2017) conducted a preliminary study with 950 engineering students on the relationship, motivation and recognition of the advantages of learning through gamified activities. The results showed a high coincidence between the participation of students with high academic performance in gamification processes ( $75 \%$ of participation time), compared to those students with low performance (from $50 \%$ to $10 \%$ of participation time). The authors identify the importance of further research and improvement to the processes of gamification for the learning interests they pursue.

Regarding meta-evaluation research, there are not as many reports as could be expected. In specialized databases, an average of 45 publications in English (ERIC database) and 15 in Spanish (in Google Academic) can be found devoted to this topic in the last 10 years. None of them address the meta-evaluative process in gamification as a didactic strategy.

\section{PROBLEM STATEMENT}

Throughout history, it has been attempted to transform education through the use of technology and innovative didactic strategies such as gamification (Salat-Figols, 2013), as several studies conducted around the world show (Dicheva, Dichev, Agre, \& Angelova, 2015, Dominguez et al., 2015, Lee \& Hammer, 2011). However, several studies have focused mainly on the relationship between gamification and motivation based on the student's perception (Faiella \& Ricciardi, 2015, Mayer 2015); therefore, learning more about the impact of the strategy in terms of improving the cognitive and teaching processes is still a pending and necessary objective.

In research developed by Rincón-Flores, Illanes and Gallardo (2016), in which the performance of the problem-solving competency was studied (Gallardo, 2016) in students when solving gamified challenges, a first effort was made to integrate the process of performance assessment into the CBEM framework. The performance assessment designed was based on the modeling cycle of Blum and Leib (2007) (see Figure 2). In their research, authors found that students improved their performance when they were provided with timely feedback for each subcompetency, but they did not improve in all of them; for example, in the subcompetencies of interpretation and validation they did not obtain favorable results. These results led us to reflect on the importance of including meta-evaluation as a means to evaluate the design of gamified activities, in order to early detect both successes and areas of opportunity. For this reason, the objective of the present study was to develop a meta-evaluative analysis (Stufflebleam, 2011) which favors the improvement of the design of gamified activities and validates the innovative role of gamification. At the same time, a model is presented to facilitate the evaluation of both student performance and innovative teaching strategies.

Accordingly, these are the premises on which this research is based:

1. Gamification contributes to the development of professional competencies, but there is little in-depth research on performance assessment that could better explain how both elements (competencies and gamification) are combined in the assessment process.

2. Previous literature on gamification has focused mainly on the production of possibilities of play activities for learning, but little on how to generate an improvement process based on the results. 


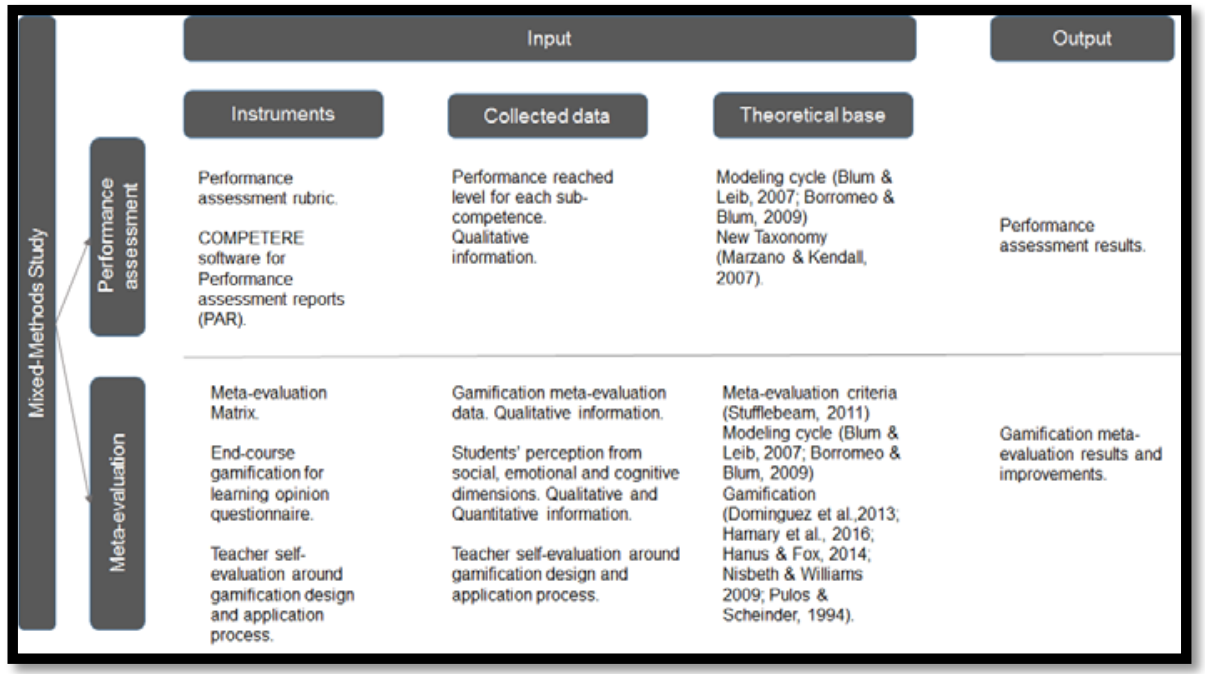

Figure 1. Method diagram

\section{METHOD}

Design. A design based on Mixed Methods (Creswell, 2015) was chosen. The approach corresponds to the sequential and dominant state explanatory type: quan-QUAL (Creswell, Plano Clark, Guttmann, \& Hanson, 1998, Creswell, 2007, Castañer, Camerino, \& Anguera, 2012). Figure 1 clarifies the manner in which the study process is approached, based on the two phenomena of interest: the performance assessment and the meta-evaluation on gamification.

Context. Research was conducted from January to May of 2017 (one semester), with the participation of two Integral Calculus groups of the undergraduate engineering program at a private institution located in the northeast of Mexico.

Participants. Fifty students participated in the study, 25 per group.

Instruments. Three instruments were designed: (a) a performance assessment rubric; (b) an inventory of questions to generate meta-evaluative processes; and (c) an assessment questionnaire on the relevance of gamified activities, with a Likert scale to better understand the process from the student's perception. The first instrument was designed based on the Blum and Leib modeling cycle (2007) and the New Taxonomy (Marzano \& Kendall, 2007) considering four levels of performance: Level 1: Retrieval, Level 2: Comprehension, Level 3: Analysis and Level 4: Knowledge Utilization. As for the processing of the data that emerged from the performance assessment process, Competere (software for institutional use, see Appendix 1) was used to generate the reports per student.

The second instrument was designed based on the proposal of Stufflebeam (2001) to conduct metaevaluative processes. The third instrument was designed based on three dimensions: cognitive, social and emotional (Domínguez et al, 2015, Hamai, 2016, Hanus \& Fox, 2014, Nisbet \& Williams, 2007, Pulos \& Sneider, 1994).

Procedure. Students were grouped in teams of four. The training work was developed using gamification based on the model by Werbach and Hunter (2015). Its execution was divided into four phases: (a) the gamified activity was carried out, which consisted of solving three challenges with a progressive level of difficulty (See Appendix 2); avatars and a board for the registration of badges were used, which were assigned as the students solved each challenge; (b) one of the gamified challenges was subjected to evaluation, which was applied individually, based on a previously designed performance assessment rubric, in which each stage of the cycle formed a subcompetency (see Figure 2); (c) a performance assessment process was applied according to the problem solving competency for the second time; (d) a questionnaire was applied to assess the perception of the students in relation to the gamification strategy; (f) the initial and final performance assessment reports were processed in a comparative manner; and (g) based on the results of the reports and the results of the Likert scale assessment instrument, the meta-evaluation was processed. 


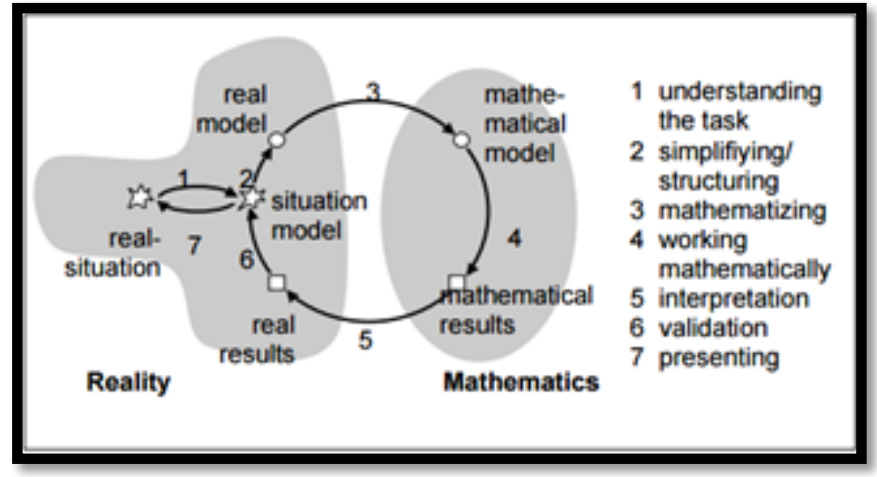

Figure 2. Stages of the modeling cycle. (Blum y Leiß 2007)

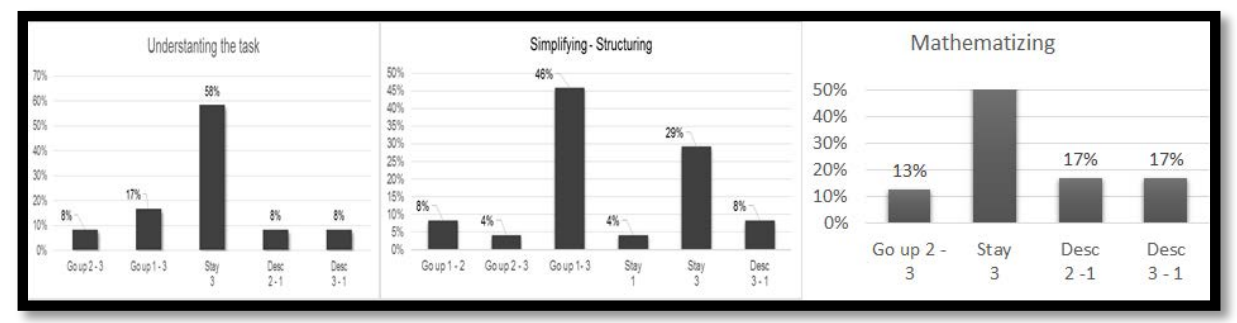

Figure 3. Results of the subcompetencies understanding the task, simplifying and Mathematizing

\section{RESULTS}

\section{Performance Assessment}

The main results of the performance assessment by subcompetency are shown in Figure 3 .

For the subcompetencies Understanding the task, Simplifying-structuring and Mathematizing, students placed within the expected performance level (58\%, 46\% and 50\% respectively). These were the percentage of students who reached levels above expectations: for Understanding the task, 17\% went up from Level 1 to Level 3, and 8\% went from Level 2 to Level 3; for Simplifying- Structuring, 8\% went up from Level 1 to Level 2 and 4\% went from Level 2 to Level 3. For Mathematizing, 13\% went up from Level 2 to Level 3.

However, it is worth noting that for the subcompetency Understanding the task, 8\% went down in their performance level, from Level 2 to Level 1, and 8\% went from Level 3 to Level 1. For the subcompetency Simplyfing-Structuring, $8 \%$ showed a decrease, from Level 3 to Level 1 . As for the subcompetency Mathematizing, 17\% showed a decrease, from Level 2 to Level 1, and 17 \% went from Level 3 to Level 1.

The results for the subcompetency Working Mathematically indicate that the level of competency expected was surpassed by most students. In this case, 25\% went from Level 1 to Level 3 and 33\% went from Level 1 to Level 4. 38\% stayed within the expected level of competency (Level 4) and 4\% stayed at Level 1.

For the subcompetency Interpreting, the expected performance level was of Level 3. 50\% of the students went up from Level 2 to Level 3, 8\% stayed at Level 3, 4\% stayed at Level 1 and another 4\% went down from Level 2 to Level 1.

The subcompetency Validating showed both increases and decreases. 38\% stayed at Level 1, 4\% stayed at Level 2 and 13\% stayed at Level 3. 8\% went up from Level 1 to Level 2, 8\% went from Level 2 to Level 3 and 17\% went from Level 1 to Level 3. 13\% went down from Level 3 to Level 2 (see Figure 4). 


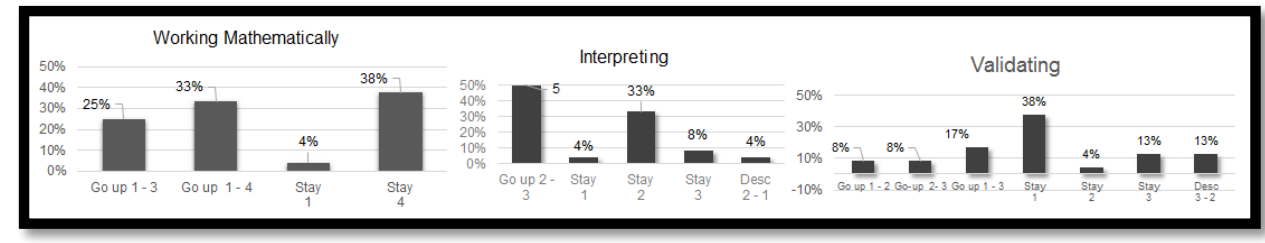

Figure 4. Results of the Working mathematically, Interpreting and Validating subcompetencies

\section{Meta-evaluation}

The information derived from the application of the meta-evaluation instrument (Stufflebeam, 2011), was organized according to three dimensions: (1) formative, (2) proactive and (3) cost.

(1) Formative dimension: Positive results were obtained, as shown in Figures 3 and 4. However, several points that could improve the training process were identified, such as: (a) Dialogue with students who have had a low performance to diagnose and better understand their needs to master the topic; (b) Apply the performance assessment at the end of the course so that both student and teacher can detect the progress and areas of opportunity that could serve as a basis for future courses; (c) Strengthen the Validation subcompetency through gamified activities, such as the processes of instruction in the classroom. This will be directly related to the redesign of the gamified challenges, as well as the activities outside and inside the classroom; and (d) Reinforce the less understood aspects reflected in the assessment, based on the didactic discourse and gamified activities.

(2) Proactive dimension: The didactic objectives were achieved, although areas of improvement were identified in terms of the design of the gamified challenges. Therefore: (a) in the subcompetency Understanding the task, it will be emphasized that, in addition to drawing the differential in the graphs, its elements must also be written down. This will favor the visualization and relationship of symbolic and graphic elements. At the same time, this measure will contribute to improvements in the subcompetencies Simplifying and Mathematizing; (b) Modify certain rules in the game, with the purpose of alleviating the frustration of some students. They will be asked to take turns in the process of writing the solution to the challenge, in order to encourage active participation from all team members.

(3) Cost dimension: The results of this dimension suggest that the gamification process requires investments both economic and in terms of teacher-hours: (a) Devoting more time to the design and application of gamified activity; (b) More time for theoretical explanation in class; (c) Design of an app for mobile devices that provides an immediate response to students during the review of results. Ideally, the answer should automatically be projected on a board once each gamified activity is finished. This would demand an economic investment to be explored with the academic authorities.

\section{Cognitive, Social and Emotional Dimensions: The Student's Perspective}

To assess the students' appreciation of the gamified activities, a Likert-type questionnaire was applied, which covered three dimensions: cognitive, social and emotional. In the cognitive dimension, the majority of students (over 90\%) are in agreement with the value of the immediate feedback, because it reinforced the metacognitive process as well as the exchange of opinions with their classmates. Regarding the emotional dimension, over $80 \%$ of the students stated that they felt motivated to beat the challenges and, therefore, see their results on the board. Finally, in the social dimension, students perceived collaborative work as a favorable resource to solve gamified challenges (over 90\%), although most would have preferred to have other teammates $(60 \%)$. In summary, the results on students' perception of gamification is positive.

\section{DISCUSSION}

Based on the assessment carried out, we observed that in the first three subcompetencies of the modeling cycle of Blum and Leib (2007) students reached the expected performance levels, although there are also opportunities for improvement (see Figures 3 and 4). These subcompetencies are related to conceptual aspects, so if the student did not understand the gamified challenge from the start, he or she would not be able to graphically visualize the differentials (Simplifying), nor symbolically pose the expressions of the differentials and volume integrals in a correct or complete manner (Mathematizing). In other words, the student could not advance to the next phase without making an error. This finding is interesting because it 
reinforces the importance of assessing the quality of innovations through the validation of the appropriate design for this type of activities (García-Peñalvo, 2015, Fidalgo-Blanco \& Sein-Echaluce, 2014, Zavalza \& Zavalza, 2012). In this case, the fact that the gamified challenges are attractive and achievable by the student and its design encourages the student to reach the level of desired performance (Marzano \& Kendal, 2007) confirms what other studies have stipulated as facts about of gamification (Plass, Homer \& Kinzer, 2015; Rincón-Flores, Ramírez-Montoya \& Mena, 2016).

Regarding the subcompetencies Working Mathematically and Interpreting, positive results were found (see Figure 3 and 4) that suggest a certain mastery of the mathematical algorithms processes (Blum \& Niss, 1991) and the association of the results with the independent and dependent variables within the context of the challenge. On the other hand, it is noteworthy that in the Validation subcompetency, a high percentage (38\%) stayed at Level 1 and 13\% went from Level 3 to Level 2. This could mean that some students did not manage to develop strategies to verify their results, which is atypical. This could be the result of the ingrained problem in the teaching-learning of Mathematics, in which the student only mechanizes the algorithmic processes (Borromeo-Ferri \& Blum, 2009) or is limited to finding a result perceived as correct (Tejada \& Gallardo, 2017).

These findings are complemented by the meta-evaluation analysis. Although the design and execution of gamified activities generate a cost in terms of time and energy, the teacher is willing to continue and perfect the design of the gamified activities, because they represent an opportunity to confront students with various challenges in a different and more pleasant environment, where, in addition to building or applying mathematical knowledge, social and emotional skills are also developed and strengthened (Muñiz-Rodriguez et al., 2014; Nisbet \& Williams, 2007).

On the other hand, the teacher will ensure that the activities associated with the didactic discourse are consistent with gamified activities and that the performance assessment exercise is replicated once more at the end of the course, in order to measure the level of progress achieved by the students. Therefore, the performance assessment (Rodriguez \& Gallardo, 2017) and meta-evaluation (Stufflebeam, 2011) are two essential teaching tasks to assess the innovative role of teaching strategies, as well as the quality of discourse.

The results of the questionnaire (see Appendix 4) also revealed that students agree that this type of didactic strategy motivates reflection and learning in an entertaining way. In addition, it favors the development of other competencies, such as collaborative work. These results coincide with what was found by Domínguez et al. (2013), Muñoz-Rodríguez et al. (2014), Nisbet and Wiliam (2009), Hamari, Shernoff, Rowe, Coller, AsbellClarke, \& Edwards (2016) and Hanus and Fox (2014). Therefore, it can be stated that the strategy is accepted by students. In addition, it favors the creation of a positive learning environment to continue applying this type of activities.

\section{CONCLUSIONS AND FUTURE WORK}

The role of gamification in the study of mathematics serves mainly as a tool for students to appropriate different learning and to develop competencies, such as modeling for this particular case (Blum \& Niss, 1991). However, the results broaden the horizons of gamification beyond it being just a fun strategy, to explain that, like any other learning strategy, its validity must be analyzed and subjected to adjustments for improvement. In fact, the success of the strategy of gamification must be supported by a consistent didactic task, which allows not only its application but also to value and make the necessary adjustments in a continuous way, so that it fully fulfills its purpose. In this sense, both the performance assessment process (Rodríguez \& Gallardo, 2017) and the meta-evaluation process (Stufflebeam, 2011) play a decisive role.

Based on the results, it can be concluded that gamification has the potential to be an innovative strategy, given the results of student satisfaction and the analysis of the performances achieved. In other words, the strategy of gamification can be improved further by understanding the scope of the activity in function of the performance reached by the students, and it is enhanced gradually, to improve the experience with each application.

It is suggested to replicate this study in order to evaluate the results once the improvements in gamified activity have been implemented. This should be applied, ideally, to learning related to the mathematical competencies that were addressed in this study. However, they could also be replicated in any other discipline that uses gamification to enrich the learning process. 


\section{Disclosure statement}

No potential conflict of interest was reported by the authors.

\section{REFERENCES}

Anderson, L. W., \& Krathwohl, D. (2001). A Taxonomy of learning teaching and assessing. Revision of Bloom's taxonomy of educational objectives. London, England: Longman.

Bartles, L., Bommer, K., \& Rubien, R.S. (2000). Student performance: Assessment centers versus traditional classroom evaluation techniques. Journal of Education for Business,75(4), 198-201. https://doi.org/10.1080/08832320009599014

Blum, W., \& Leiß, D. (2007). How do students' and teachers deal with modelling problems? In: C. Haines, et al. (Eds.), Mathematical Modelling: Education, Engineering and Economics. Chichester: Horwood , 222231. https://doi.org/10.1533/9780857099419.5.221

Blum, W., \& Niss, M. (1991). Applied Mathematical Problem Solving, Modelling, Applications, and Links to Other Subjects: State, Trends and Issues in Mathematics Instruction. Educational Studies in Mathematics, 22(1), 37-68. https://doi.org/10.1007/BF00302716

Bogo, M., Regehr, C., Woodford, M., Hughes, J., Power, R., \& Regehr, G. (2006). Beyond competencies: Field instructors' descriptions student performance. Journal of Social Work Education, 42(3), 579-593. https://doi.org/10.5175/JSWE.2006.200404145

Borromeo, R., \& Blum, W. (2009). Mathematical Modelling: Can it be taught and learnt? Journal of Mathematical Modelling and Application, 1(1), 45-58.

Caponetto, I., Earp, J., \& Ott, M. (2014). Gamification and Education: A Literature Review. Proceedings of the European Conference on Games Based Learning, 1(October), 50-57. Retrieved from http://search.ebscohost.com/login.aspx?direct=true\&db=eue\&AN=99224935\&site=ehost-live

Castañer, M., Camerino, O., \& Anguera, M. T. (2013). Métodos mixtos en la investigación de las ciencias de la actividad física y el deporte. Apuntes Educación Física y Deportes, (112), 31-36. Retrieved from http://dialnet.unirioja.es/servlet/articulo?codigo=4419351

Chamoso, J., Durán, J., García, J., Martín, J., \& Rodríguez, M. (2004). Análisis y experimentación de juegos como instrumentos para enseñar matemáticas, SUMA, (47), 47-58.

Corbalán, F. (2000). Algunos aspectos de matemáticas recreativas. In A. M. Cejas (ed.), Las matemáticas del siglo XX, una mirada en 101 artículos (pp. 121-124). España: Universidad de La Laguna, Sociedad Canaria Isaac Newton de Profesores de Matemáticas, Nivola.

Creswel, J. W. (2015). A concise introduction to mixed methods research. Thousand Oaks, CA, USA: SAGE.

Creswell, J. W., Plano Clark, V. L., Guttmann, M. L., \& Hanson, E. E. (2003). Advanced mixed methods research design. In A. Tashakkori and C. Teddlie (Eds.), Handbook of mixed methods in social and behavioral research (pp. 209-240). Thousand Oaks, CA: Sage.

Davis, K., \& Singh, S. (2015). Digital badges in afterschool learning: Documenting the perspectives and experiences of students and educators. Computers and Education, 88, 72-83. https://doi.org/10.1016/j.compedu.2015.04.011

De la Cruz, G., Chung, G., \& Baker, E. (2010). Validity evidence for games as assessment environments. National Center for Research on Evaluation, Standards, and Student Testing: UCLA.

Deterding, S., Khaled, R., Nacke, L., \& Dixon, D. (2011). Gamification: toward a definition. Chi 2011, 12-15. http://doi.org/978-1-4503-0268-5/11/0

Daigneault, P. M. (2008). L'examen de la qualité des évaluations fédérales: une méta-évaluation réussie? The Canadian Journal of Program Evaluation, 23(2), 191. Retrieved from http://0search.proquest.com. millenium.itesm. $\mathrm{mx} /$ docview/365465735?accountid=41938

Dicheva, D., Dichev, C., Agre, G., \& Angelova, G. (2015). Gamification in education: A systematic mapping study. Educational Technology and Society, 18(3), 75-88. Retrieved from http://www.scopus.com/inward/record.url?eid=2-s2.0-84938082996\&partnerID=tZOtx3y1

Deulofeu, J. (2001). Una recreación matemática: historias, juegos y problemas. Barcelona: Planeta.

Domínguez, A., Saenz-De-Navarrete, J., De-Marcos, L., Fernández-Sanz, L., Pagés, C., \& Martínez-Herráiz, J. J. (2013). Gamifying learning experiences: Practical implications and outcomes. Computers and Education, 63, 380-392. http://doi.org/10.1016/j.compedu.2012.12.020 
Faiella, F., \& Ricciardi, M. (2015). Gamification and learning: A review of issues and research. Journal of $E$ Learning and Knowledge Society. Italian e-Learning Association.

Fidalgo, Á., \& Sein-Echaluce, M. L. (2014). Educational innovation. Proceedings of the Second International Conference on Technological Ecosystems for Enhancing Multiculturality - TEEM '14, 17 (March), 65-67. Retrieved from http://dl.acm.org/citation.cfm?doid=2669711.2669880

Gallardo Córdova, K. E. (2016). Resolver problemas. In Valenzuela González. (Ed.), Competencias transversales para una sociedad basada en conocimiento (pp. 104-123). Ciudad de México, México: Cengage Learning Editores.

García-Peñalvo, F. J., García de Figuerola, C., \& Merlo, J. A. (2010). Open knowledge: challenges and facts. Online Information Review, 34(4), 520-539. http://doi.org/10.1108/14684521011072963

García-Peñalvo, F. J. (2015). Mapa de tendencias en Innovación Educativa. Teoria de La Educacion, 16(4), 623. http://doi.org/10.14201/eks2015164623

Goehle, G. (2013). Gamification and web-based homework. Primus, 23(3), 234-246. https://doi.org/10.1080/10511970.2012.736451

Gomez Chacón, I. (2000). Matemática emocional: los afectos en el aprendizaje matemático. Madrid: Narcea.

Hamari, J., Shernoff, D. J., Rowe, E., Coller, B., Asbell-Clarke, J., \& Edwards, T. (2016). Challenging games help students learn: An empirical study on engagement, flow and immersion in game-based learning. Computers in Human Behavior, 54, 170-179. https://doi.org/10.1016/j.chb.2015.07.045

Hancock, D. (2007). Effects of performance assessment on the achievement and motivation of graduate students. Active Learning in Higher Education, 8(3), 219-231. https://doi.org/10.1177/1469787407081888

Hanus, M., \& Fox, J. (2014). Assessing the effects of gamification in the classroom: A longitudinal study on intrinsic motivation, social comparison, satisfaction, effort, and academic performance, Computers \& Education, (80), 152-161.

Jackson, C., de Beer, J., \& White, L. (2016). Teachers'affective development during an indigenous knowledge professional teacher intervention. Retrieved http://uir.unisa.ac.za/bitstream/handle/10500/22851/Cherine\%20Jackson,\%20Josef\%20de\%20Beer, \%2 OLounell\%20White.pdf? sequence=1

Kebritchi, M., Hirumi, A., \& Bai, H. (2010). The effects of modern mathematics computer games on mathematics achievement and class motivation. Computers \& Education, 55(2), 427-443. https://doi.org/10.1016/j.compedu.2010.02.007

Kent, T. (2004). Learning taxonomies in the cognitive, affective and psychomotors domains. Retrieved from http://www.rockymountainalchemy.com/whitePapers/rma-wp-learning-taxonomies.pdf

Lee, J., \& Hammer, J. (2011). Gamification in Education: What, How, Why Bother? Academic Exchange Quarterly, 15(2).

López Fernández, D., Alarcón Cavero, P. P., Rodríguez Sánchez, M., \& Casado Fuente, M. L. (2014). Motivación en estudiantes de ingeniería: Un caso de estudio con teorías e instrumentos para su medida y desarrollo. Motivation on engineering students: A case study using theories and instruments for its measurement and Introducción. Revista de Docencia Universitaria, 12(4), 343-376. https://doi.org/10.4995/redu.2014.5627

Marzano R. J., \& Kendall, J. S. (2007). The new taxonomy of educational objectives. Thousand Oaks, California, EE.UU.: Corwnin Press.

Mayer, R. E. (2015). On the Need for Research Evidence to Guide the Design of Computer Games for Learning. Educational Psychologist, 50(4), 349-353. http://doi.org/10.1080/00461520.2015.1133307

Muñiz-Rodriguez, L., Alonso, P., \& Rodriguez-Muñiz, L. (2014). El uso de los juegos como recurso didáctico para la enseñanza y el aprendizaje de las Matemáticas. Revista Iberoamericana de Educación Matemática, 39, 19-33. Retrieved from http://www.fisem.org/www/union/revistas/2014/39/archivo6.pdf

Nisbet, S., \& Williams, A. (2009). Improving students' attitudes to chance with games and activities. Australian Mathematics Teacher, 65(3), 25-37.

Patton, M. Q. (2012). Meta-evaluation: Evaluating the evaluation of the Paris Declaration. The Canadian Journal of Program Evaluation, 27(3), 147-171.

Plass, J. L., Homer, B. D., \& Kinzer, C. K. (2015). Foundations of Game-Based Learning. Educational Psychologist, 50(4), 258-283. https://doi.org/10.1080/00461520.2015.1122533 
Pulos, S., and Sneider, C. (1994). Designing and evaluating effective games for teaching science and mathematics: An illustration form coordinate geometry. Focus on Learning Problems in Mathematics, $16(3), 23-42$.

Ramírez-Montoya, M. S. (2012). Modelos y estrategias de enseñanza para ambientes innovadores. México: Editorial Digital. Tecnológico de Monterrey.

Rincón-Flores, E., Ramírez-Montoya, M. S., \& Mena, J. (2016). Challenge-based gamification and its impact in teaching mathematical modeling. In Proceedings of the fourth International Conference on Technological Ecosystems for Enhancing Multiculturality, TEEM 2016. https://doi.org/10.1145/3012430.3012605

Rincón, E., Illanes, L., \& Gallardo, K. (2016). Gamificación y su efecto en la competencia de resolución de problemas. Memorias del III Congreso Internacional de Innovación Educativa. Retrieved from http://ciie.mx/memorias/

Rodríguez, F., \& Santiago, R. (2015). Gamificación: cómo motivar a tu alumnado y mejorar el clima en el aula. Barcelona, España: Grupo Oceano.

Rodríguez, I., \& Gallardo, K. E. (2017). Redesigning an Educational Technology Course under a CompetencyBased Performance Assessment Model. Pedagogika, 127(3), 184-204. Retrieved from https://goo.gl/5mouhE

Rubia Avi, B., Anguita Martínez, R., \& Jarrín Abellán Inés Ruiz Requies, I. (2010). Educative Innovation Process in University Formation, New Productive Bests Practices in Educative Technology. Tesi, 11(113), 96-120.

Salat Figols, R. S. (2013). La enseñanza de las matemáticas y la tecnología. Innovación Educativa, 13, 61-74. Retrieved from http://www.redalyc.org/articulo.oa?id=179429882005

Sánchez-Carmona, A., Robles, S., \& Pons, J. (2017). Journal of Technology and Science Education, 7(2), 150161. https://doi.org/10.3926/jotse.246

Stufflebeam, D. L. (2001). The Metaevaluation Imperative. American Journal of Evaluation, $22(2), 183$. https://doi.org/10.1177/109821400102200204

Stufflebeam, D. (2011). Meta-evaluation. Journal of Multidisciplinary Evaluation, 7(15), 99-158.

Surendeleg, G., Murwa, V., Yun, H. K., \& Kim, Y. S. (2014). The role of gamification in education-a literature review. Contemporary Engineering $\quad$ Sciences, $\quad 7(29-32), \quad 1609-1616$. http://doi.org/10.12988/ces.2014.411217

Tay, H. Y. (2015). Setting formative assessments in real-world contexts to facilitate self-regulated learning. Educational Research for Policy and Practice, 14(2), 169-187. http://doi.org/10.1007/s10671-015-91725

Tejeda, S. \& Gallardo, K. E. (2017). Performance Assessment on High School Advanced Algebra. International Electronic Journal of Mathematics Education, 12(9), 777-798. Retrieved from http://iejme.com/makale/1979

Tobias, S., \& Weissbrod, C. (1980). Anxiety and mathematics: An update. Harvard Educational Review, 50(1), 63-70. https://doi.org/10.17763/haer.50.1.xw483257j6035084

Tsai, M.-J., Huang, L.-J., Hou, H.-T., Hsu, C.-Y., \& Chiou, G.-L. (2016). Visual Behavior, Flow and Achievement in Game-Based Learning. Computers \& Education, 98, 115-129. https://doi.org/10.1016/j.compedu.2016.03.011

Vásquez, F. O. V. (2015). La taxonomía psicomotora en el laboratorio-taller mecánico de la educación. Revista Vinculándonos. Retrieved from http://vinculando.org/?s=psicomotor

Zabalza Beraza, M. A., \& Zabalza Cerdeiriña, M. A. (2012). Innovación y cambio en las instituciones educativas. Rosario, Argentina: Homo Sapiens Ediciones.

Website for more information about the instruments of research. Documents are available in native language: https://goo.gl/kXHqkq 


\section{APPENDIX}

Table 1. Performance assessment rubric based on the new competency-based model

\begin{tabular}{|c|c|c|c|c|c|c|}
\hline $\begin{array}{l}\text { Disciplinary } \\
\text { and transversal } \\
\text { competencies }\end{array}$ & $\begin{array}{l}\text { Disciplinary } \\
\text { subcompetencies }\end{array}$ & Short name & Level 1 & Level 2 & Level 3 & Level 4 \\
\hline \multirow[t]{6}{*}{$\begin{array}{l}\text { 1. Use of } \\
\text { modeling to solve } \\
\text { problems using } \\
\text { integral calculus } \\
\text { to make decisions } \\
\text { in situations } \\
\text { specific to } \\
\text { engineering } \\
\end{array}$} & $\begin{array}{l}\text { 1.1 Understands the } \\
\text { elements composing a } \\
\text { real-life or simulated } \\
\text { problem which } \\
\text { requires knowledge of } \\
\text { differentials }\end{array}$ & Construction & $\begin{array}{l}\text { Identifies the } \\
\text { essential elements } \\
\text { that make up the } \\
\text { problem based on } \\
\text { the differentials }\end{array}$ & \multirow{2}{*}{$\begin{array}{l}\text { Explains the } \\
\text { relationships } \\
\text { between the } \\
\text { differentials that } \\
\text { make up a problem } \\
\text { and detects } \\
\text { missing elements } \\
\text { that conform the } \\
\text { volume. The } \\
\text { explanation can be } \\
\text { oral or graphical } \\
\text { using a diagram of } \\
\text { the problem. }\end{array}$} & \multirow{2}{*}{$\begin{array}{l}\text { In addition to } \\
\text { explaining of the } \\
\text { relationship of the } \\
\text { existing } \\
\text { differentials in the } \\
\text { problem, associates } \\
\text { elements from } \\
\text { previous problems } \\
\text { and/or previous } \\
\text { knowledge that } \\
\text { could be similar or } \\
\text { pertinent to the } \\
\text { new problem, which } \\
\text { could be useful to } \\
\text { navigate the latter. }\end{array}$} & \\
\hline & $\begin{array}{l}\text { 1.2 Summarizes } \\
\text { verbally and } \\
\text { graphically the } \\
\text { elements that make } \\
\text { up the problem. }\end{array}$ & $\begin{array}{l}\text { Simplification and } \\
\text { structuring }\end{array}$ & $\begin{array}{l}\text { Charts a diagram } \\
\text { containing the } \\
\text { differentials but } \\
\text { without making the } \\
\text { appropriate } \\
\text { connections between } \\
\text { them to include } \\
\text { them in the problem }\end{array}$ & & & \\
\hline & $\begin{array}{l}\text { 1.3 Carries out } \\
\text { processes of inductive } \\
\text { and deductive } \\
\text { thinking through the } \\
\text { mathematical } \\
\text { representation of the } \\
\text { problem }\end{array}$ & Mathematization & $\begin{array}{l}\text { Using the diagram, } \\
\text { describes the } \\
\text { problem's } \\
\text { differentials, yet } \\
\text { without carrying } \\
\text { out a comparative } \\
\text { process with } \\
\text { theoretical aspects } \\
\text { previously studied. }\end{array}$ & $\begin{array}{l}\text { Explains which } \\
\text { differentials can be } \\
\text { found in the } \\
\text { problem. Does not } \\
\text { draft a proposal of } \\
\text { a mathematical } \\
\text { representation of } \\
\text { the differential to } \\
\text { solve the problem. }\end{array}$ & $\begin{array}{l}\text { Associates the use } \\
\text { of the differential } \\
\text { with a } \\
\text { mathematical } \\
\text { representation to } \\
\text { solve the problem. }\end{array}$ & \\
\hline & $\begin{array}{l}\text { 1.4 Applies a series of } \\
\text { algorithmic tools } \\
\text { (numerical and/or } \\
\text { algebraic integration } \\
\text { techniques) with } \\
\text { processes and } \\
\text { symbology } \\
\text { appropriate to the } \\
\text { problem. }\end{array}$ & & $\begin{array}{l}\text { Describes the } \\
\text { integration } \\
\text { techniques (from } \\
\text { the differential and } \\
\text { the functions) that } \\
\text { could be useful to } \\
\text { solve the problem. }\end{array}$ & $\begin{array}{l}\text { Applies the } \\
\text { integration } \\
\text { techniques (from } \\
\text { the differential and } \\
\text { the functions) to } \\
\text { solve the problem, } \\
\text { not necessarily } \\
\text { knowing which is } \\
\text { the correct one. }\end{array}$ & $\begin{array}{l}\text { Works out the type } \\
\text { of techniques that } \\
\text { could be used based } \\
\text { on the nature of the } \\
\text { function. However, } \\
\text { does not opt for one, } \\
\text { but various } \\
\text { techniques with } \\
\text { similar } \\
\text { characteristics. } \\
\text { Might choose the } \\
\text { correct one but the } \\
\text { decision isn't based } \\
\text { on solid arguments. }\end{array}$ & $\begin{array}{l}\text { Chooses the } \\
\text { appropriate } \\
\text { technique using } \\
\text { a process of } \\
\text { reflection, based } \\
\text { on solid } \\
\text { arguments. }\end{array}$ \\
\hline & $\begin{array}{l}\text { 1.5 Interprets the } \\
\text { results } \\
\text { contextualizing the } \\
\text { solutions. }\end{array}$ & Interpretation & $\begin{array}{l}\text { Provides a result } \\
\text { without integration } \\
\text { to the context. }\end{array}$ & $\begin{array}{l}\text { Provides the } \\
\text { results indicating } \\
\text { just the } \\
\text { measurement units } \\
\text { but without } \\
\text { providing context } \\
\text { to the solution. } \\
\end{array}$ & $\begin{array}{l}\text { Provides the result } \\
\text { indicating the } \\
\text { measurement units } \\
\text { and contextualizes } \\
\text { the answer. }\end{array}$ & \\
\hline & $\begin{array}{l}\text { 1.6 Validates the } \\
\text { results of testing the } \\
\text { solution with the } \\
\text { problem supported by } \\
\text { technology. }\end{array}$ & Validation & $\begin{array}{l}\text { Does not identify } \\
\text { errors even when } \\
\text { using technology to } \\
\text { support error } \\
\text { detection. }\end{array}$ & $\begin{array}{l}\text { Identifies the } \\
\text { existence of errors } \\
\text { using technology, } \\
\text { but cannot find or } \\
\text { explain the causes. }\end{array}$ & $\begin{array}{l}\text { Verifies, using } \\
\text { technology, that the } \\
\text { result is correct and } \\
\text { consistent with the } \\
\text { theoretical and } \\
\text { particular aspects } \\
\text { of the problem's } \\
\text { nature. }\end{array}$ & \\
\hline
\end{tabular}

